\title{
SCREENING OF RESISTANCE TO EgYPTIAN BROOMRAPE INFECTION IN TOMATO VARIETIES ${ }^{1}$
}

\author{
Triagem de Resistência à Infecção pela Erva-Toira do Egito em Variedades de Tomate
}

TOKASI, S. ${ }^{2}$, BANNAYAN AVAL, M. ${ }^{2}$, MASHHADI, H.R. ${ }^{2}$, and GHANBARI, ALI. ${ }^{2}$

\begin{abstract}
Parasitic weed species of the genus Orobanche are serious threat for the production of several crops in Europe, Africa and Asia. Research on resistant host plant varieties is one of the most effective management strategies for this parasitic weed. In this study, the susceptibility of twenty-nine tomato varieties to broomrape infection (Orobanche aegyptiaca) under greenhouse conditions was investigated. The employed experimental design was completely randomized with three replications. Differences in susceptibility to infection were monitored among tomato varieties based on their difference in the number of emerged shoots of broomrape and broomrape dry weight (shoots and tubercles). Date of Orobanche emergence varied over a period of 3 to 30 days between varieties. Very late infection was monitored for varieties of Cal-jN3, Viva, Caligen 86, Packmor, CSX 5013, Hyb. PS 6515 and Hyb Petopride5. Differences in the growth and fruit yield among tomato varieties were also found in response to broomrape infestation. Moderate levels of resistance were obtained in Viva, Caligen 86, Hyb. PS 6515, Hyb.Firenze (PS 8094) and Cal-jN3 among other tomato varieties. In contrast, varieties of Kimia-Falat, Hyb. Petopride II and Hyb.AP865 were the most susceptible hosts to Orobanche aegyptiaca.
\end{abstract}

Keywords: breeding, Orobanche aegyptiaca, Lycopersicon esculentum, parasitic plant, weed.

\begin{abstract}
RESUMO - Espécies de plantas daninhas parasitas do gênero Orobanche são uma séria ameaça à produção de diversas culturas na Europa, África e Ásia. A realização de pesquisas com variedades resistentes de plantas hospedeiras é uma das estratégias de manejo mais eficazes com relação a essa planta daninha parasita. Neste estudo, foi investigada, em casa de vegetação, a susceptibilidade de vinte e nove variedades de tomate à infecção pela erva-toira do Egito (Orobanche aegyptiaca). O delineamento experimental utilizado foi inteiramente casualizado, com três repetições. As diferenças de susceptibilidade à infecção foram monitoradas entre as variedades de tomate com base na diferença entre o grau de emergência da parte aérea da erva-toira e a massa seca da erva-toira (parte aérea e tubérculos). A data de emergência da Orobanche variou entre as variedades ao longo de um periodo de 3 a 30 dias. Foi observada uma infecção bastante tardia para as variedades Cal-JN3, Viva, Caligen 86, Packmor, CSX 5013, Hyb. OS 6515 e Hyb Petopride5. Também foram encontradas diferenças no crescimento e produção de frutos entre as variedades de tomate em resposta à infestação da erva-toira. Niveis moderados de resistência foram obtidos nas variedades de tomate Viva, Caligen 86, Hib. OS 6515, Hyb.Firenze (OS 8094) e Cal-jN3, entre outras. Em contrapartida, KimiaFalat, Hib. Petopride II e Hyb.AP865 foram as variedades anfitriãs mais suscetiveis a Orobanche aegyptiaca.
\end{abstract}

Palavras-chave: reprodução, Orobanche aegyptiaca, Lycopersicon esculentum, planta parasita, planta daninha.

1 Recebido para publicação em 11.5.2013 e aprovado em 28.82013.

2 University of Mashhad, Mashhad, Irã, <stokasi@yahoo.com>. 


\section{INTRODUCTION}

Egyptian broomrape (Orobanche aegyptiaca) is a chlorophyll-lacking root parasite, dicotyledonous flowering plant (Joel et al., 2007) that is able to take carbohydrates from the phloem and water and minerals from the xylem of the host by means of a connection to the host vascular tissues (Fernandez-Aparicio et al., 2009). Infection by Orobanche causes severe yield and quality losses. Heavy infections can cause more than 50\% reduction in yields and severe quality losses in parsley (Petroselinum crispum) including leaf chlorosis and contamination of plant material by broomrape shoots (Goldwasser \& Kleifeld, 2002). Orobanche can parasitize many dicotyledonous species (Eizenberg et al., 2003). Tomato (Lycopersicon esculentum) is one of the most important vegetable crops in Iran that is highly susceptible to damage by $O$. aegyptiaca. The main threat of this weed originates from its high multiplication rate, arising from the production of a large number of minusculesized seeds. Seeds have long viability in the soil (Abbes et al., 2007). Buried seeds germinate only after stimulation by root exudates of the host. This makes the control of the parasite in agricultural areas extremely difficult (Zhou et al., 2004; Sillero et al., 2005).

Some strategies for broomrape control have been developed, ranging from cultural practices to chemical control but all without unequivocal success because they were not feasible, uneconomic, and hard to achieve or resulted in incomplete protection (Joel et al., 2007; Fernandez-Aparicio et al., 2009). As Orobanche requires stimulants exuded by the host roots in order to germinate and reach the host root, varieties that exude these stimulants at low levels could be suitable for reducing Orobanche infection. Using resistant varieties is the most economical, feasible, and environmental-friendly method of parasitic weed control (Rubiales et al., 2003; Abbes et al., 2007). Host genetic resistance is also generally considered to be critical to successful integrated pest management programs (Rubiales et al., 2003). Plant resistance level to a parasitic weed can be estimated by measurement of different indicators such as total parasite weight per host plant, average height of parasitic flowering shoots, number of emerged parasites per sown surface unit and number of emerged spikes per host plant (Rubiales et al., 2006). Although the number of emerged spikes per host plant appears to be the best index (Rubiales et al., 2003), screening of only this index might display bias when the health of the host plant also has to be taken into consideration (Sillero et al., 1996). Useful levels of resistance have been found in several reports for tomato plants against Orobanche sp. (Mariam \& Suwanketnikom, 2004; El-Halmouch et al., 2006; Dor et al., 2010).

Several possible mechanisms have been suggested for the resistance phenomenon, such as (i) secretion of inhibitors (phytoalexins) by the resistant host (Serghini et al., 2001), (ii) increased production of phytotoxins by the host roots in response to Orobanche spp. penetration (Eizenberg et al., 2001), and (iii) condensation and lignification of root cell walls and increased activity of specific enzymes involved in the defense response (Goldwasser et al., 1999). Labrousse et al. (2001), on a daily observation of the pathosystem and in particular in a kinetic study of the parasite seed germination, showed that resistance is often due to a lack of stimulation of parasite germination by the Lycopersicon root exudates. In addition, the exudation of inhibitors may prevent host recognition by the parasite and its germination (Whitney \& Carstein, 1981).

The aim of this study was to assess the resistance level of twenty nine tomato varieties to O. aegyptiaca infection.

\section{MATERIALS AND METHODS}

Seeds of tomato (Lycopersicon esculentum) varieties were obtained from 'Iran Falat Company' and those of broomrape (Orobanche aegyptiaca) were collected from infected tomato fields of Mashhad, in Iran. Fully matured stems of the parasite were collected and dried under room conditions and the seeds were separated by sieves. Seeds were stored in a refrigerator at $4{ }^{\circ} \mathrm{C}$ until cultivation. The experiment was conducted under controlled greenhouse conditions at $20{ }^{\circ} \mathrm{C} / 30{ }^{\circ} \mathrm{C}$ (night and day) with an average of $14 \mathrm{~h}$ of natural daylight during the year 2010. The experimental design was completely randomized with three 
replications. Three infested pots were prepared for each tomato variety. As control, three noninfested pots were prepared for each tomato variety. Broomrape seeds (10 $\mathrm{mg} \mathrm{kg}^{-1}$ of soil) were mixed in a potting mix of $1: 1: 1$ (peat-sandclay). Each plastic pot (22 cm diameter) was $18 \mathrm{~cm}$ in height with holes at the bottoms and filled with $7 \mathrm{~kg}$ of potting mix. The pots were watered every day for 10 days at $25^{\circ} \mathrm{C}$ to obtain preconditioned broomrape seeds. Then one tomato seedling was planted in each pot. Irrigation, fertilization and pest control were applied when required. Twenty nine varieties of tomato (Table 1) were used in this experiment.

Broomrape parasitism was classified into two categories, i.e., broomrape shoots and tubercles. The Orobanche shoots that emerged above the soil were counted weekly. At the end of the experiment, three months after sowing, the final number of emerged parasite shoots per host plant was counted and removed. Tomato shoots were harvested from soil surface. Roots were separated from the soil by careful washing under running water and tubercles of broomrape were carefully dissected from tomato roots and weighted. Total plant material was dried at $70{ }^{\circ} \mathrm{C}$ for $48 \mathrm{~h}$. The data collected were the numbers of broomrape shoots and dry weight of broomrape shoots and tubercles and dry weight of shoot, root and fruit of tomatoes in infested and noninfested plants. Reduction percentage was calculated for tomato shoot, root and fruit for each infested variety treatment compared to non-infested variety. Statistical analysis was performed using the $\mathrm{R}$ (package 'Scottknott') software and, for analysis of variance, the Scott-Knott test at $p=0.05$ level of probability was used to determine significant differences between treatment means.

\section{RESULTS AND DISCUSSION}

Significant differences were observed among tomato varieties for all measured parameters $(\mathrm{P}<0.05)$ under both broomrape infested and non-infested conditions (Table 1). Tomato plants grown in Orobanche infested soil showed smaller shoot, root and fruit dry weight than the non-infested condition. This result indicated the strong negative effects of broomrape on tomato plant growth. Under noninfested condition, Viva, Cal-jN3, CSX 0005 and Rio Grande varieties with 65.2, 65, 62.9 and $61.5 \mathrm{~g}$, respectively, produced the highest tomato shoot dry weight as compared to other varieties (Table 1). The varieties Hyb. Alex 63 F1(XP 02500006), with 5.5\% reduction of shoot dry weight, and Kimia-Falat cultivar, with $70.4 \%$ reduction of shoot dry weight, were the most resistant and susceptible varieties (Table 2). The varieties Hyb.PS 6515, Caligen 86, Viva, Hyb. Speedy and Super 2274, with $6.8,7.8,10.7,11.7$ and $14.4 \%$ reduction, respectively, did not show significant differences compared with Hyb. The cultivar Alex 63 F1(XP 02500006) and the varieties Hyb. Berlina (CS 02500008) and Hyb.AP865, with $68.1 \%$ and $62 \%$ reduction, respectively, did not show significant differences compared with Kimia-Falat cultivar (Table 2).

In evaluating tomato varieties based on tomato root dry weights, the non-infested plant of Caligen 86, with 88.86 g plant $^{-1}$, produced the highest root biomass (Table 1). The varieties Rio Grande, Hyb.Berlina, Cal-jN3, Viva, CSX 0005 and Super 2274, with 69.5, $75.6,56.4,53.8,51$ and $51 \mathrm{~g}$, respectively, were the other varieties that produced more root biomass than other varieties (Table 1). The varieties that had larger root system resulted in less tubercle per gram of roots. The infested Viva cultivar, with $14.4 \%$ reduction of tomato root dry weight compared with its non-infested plant, was the most resistant variety. The Packmor cultivar, with $73.3 \%$ reduction compared with its non-infested plant, was the most susceptible variety according to this parameter (Table 2). The Caligen 86 cultivar, with $19.5 \%$ reduction, did not show significant differences compared with the Viva cultivar. The varieties Hyb. Petopride II, Kimia-Falat, Hyb.FTM 5456, Hyb.Ap865 and Hyb.EX02530416, with 71.5, 68.5, 65, 64.3 and $63.5 \%$ reduction, respectively, did not show significant differences compared with the Packmor cultivar (Table 2). The reduction in tomato root growth indicated strong competition between this sink and Orobanche. However, this loss of biomass was compensated by broomrape biomass.

Fruit dry weight showed that the varieties CSX 0005, Viva and Hyb.Eden, with 90.3, 86.9 
Table 1 - Mean comparison of shoot, root and fruit dry weight of non-infested and infested tomato plants (g)

\begin{tabular}{|c|c|c|c|c|c|c|}
\hline \multirow[t]{2}{*}{ Tomato variety } & \multicolumn{3}{|c|}{$\begin{array}{l}\text { Tomato dry weight }(\mathrm{g}) \\
\text { (non-infested plants) }\end{array}$} & \multicolumn{3}{|c|}{$\begin{array}{l}\text { Tomato dry weight (g) } \\
\text { (infested plants) }\end{array}$} \\
\hline & Shoot & Root & Fruit & Shoot & Root & Fruit \\
\hline Caligen 86 & $58.38 \mathrm{~b}$ & $88.86 \mathrm{a}$ & $68.5 \mathrm{c}$ & $55.03 \mathrm{a}^{\frac{1}{}}$ & $13.54 \mathrm{~g}$ & $37.62 \mathrm{~d}$ \\
\hline Cal-jN3 & $65.03 \mathrm{a}$ & $56.38 \mathrm{c}$ & $54.8 \mathrm{e}$ & $53.59 \mathrm{a}$ & $46.44 \mathrm{a}$ & $38.44 \mathrm{~d}$ \\
\hline chef & $33.13 \mathrm{~d}$ & $14.16 \mathrm{i}$ & $33.69 \mathrm{~h}$ & $15.16 \mathrm{~g}$ & $9.97 \mathrm{~g}$ & $9.59 \mathrm{~g}$ \\
\hline CSX 0005 & $62.89 \mathrm{a}$ & $51.05 \mathrm{~d}$ & $90.28 \mathrm{a}$ & $42.3 \mathrm{~b}$ & $33.38 \mathrm{c}$ & $53.04 \mathrm{~b}$ \\
\hline CSX 5013 & $43.69 \mathrm{c}$ & $31.12 \mathrm{~g}$ & $16.35 \mathrm{j}$ & $32.3 \mathrm{~d}$ & $15.81 \mathrm{f}$ & $12.22 \mathrm{~g}$ \\
\hline CSX 9062 & $55.71 \mathrm{~b}$ & $47.67 \mathrm{e}$ & $58.25 \mathrm{e}$ & $42.47 \mathrm{~b}$ & $35.85 \mathrm{~b}$ & $42.83 \mathrm{c}$ \\
\hline Early Urbana Y & $44.3 \mathrm{c}$ & $44.16 \mathrm{e}$ & $62.83 \mathrm{~d}$ & $32.95 \mathrm{~d}$ & $29.17 \mathrm{c}$ & $52.96 \mathrm{~b}$ \\
\hline Hyb.Alex 63 F1(XP 02500006) & $36.71 \mathrm{~d}$ & $27.49 \mathrm{~h}$ & $36.22 \mathrm{~g}$ & $26.36 \mathrm{f}$ & $28.3 \mathrm{~b}$ & $24.29 \mathrm{e}$ \\
\hline Hyb.AP865 & $36.79 \mathrm{~d}$ & $25.07 \mathrm{~h}$ & $37.61 \mathrm{~g}$ & $17.76 \mathrm{~g}$ & $16.29 \mathrm{f}$ & $21.65 \mathrm{f}$ \\
\hline Hyb.Berlina(CS 02500008) & $47.68 \mathrm{c}$ & $57.64 \mathrm{c}$ & $33.15 \mathrm{~h}$ & $25.22 \mathrm{f}$ & $31.54 \mathrm{c}$ & $13.3 \mathrm{~g}$ \\
\hline Hyb.Eden F1 & $53 \mathrm{~b}$ & $44.12 \mathrm{e}$ & $86.54 \mathrm{a}$ & $44.76 \mathrm{~b}$ & $32.28 \mathrm{c}$ & $54.25 \mathrm{~b}$ \\
\hline Hyb.EX 02530416 & $44.11 \mathrm{c}$ & $28.99 \mathrm{~h}$ & $32.76 \mathrm{~h}$ & $25.34 \mathrm{f}$ & $16.92 \mathrm{f}$ & $14.58 \mathrm{~g}$ \\
\hline Hyb.Firenze (PS 8094) & $34.69 \mathrm{~d}$ & $35.61 \mathrm{f}$ & $38.05 \mathrm{~g}$ & $25.52 \mathrm{f}$ & $21.92 \mathrm{~d}$ & $24.08 \mathrm{e}$ \\
\hline Hyb.FTM 5456 & $55.55 \mathrm{~b}$ & $36.44 \mathrm{f}$ & $39.46 \mathrm{~g}$ & $25.47 \mathrm{f}$ & $14.73 \mathrm{f}$ & $11.76 \mathrm{~g}$ \\
\hline Hyb.Petopride 5 & $31.61 \mathrm{~d}$ & $32.15 \mathrm{~g}$ & $72.14 \mathrm{c}$ & $19.94 \mathrm{~g}$ & $29.69 \mathrm{c}$ & $20.06 \mathrm{f}$ \\
\hline Hyb.Petopride II & $47.47 \mathrm{c}$ & $24.0 \mathrm{~h}$ & $45.84 \mathrm{f}$ & $25.36 \mathrm{f}$ & $15.50 \mathrm{f}$ & $14.19 \mathrm{~g}$ \\
\hline Hyb.PS 6515 & $46.03 \mathrm{c}$ & $26.84 \mathrm{~h}$ & $67.05 \mathrm{c}$ & $35.21 \mathrm{~d}$ & $16.18 \mathrm{f}$ & $44.14 \mathrm{c}$ \\
\hline Hyb.PX 02410739 & $34.38 \mathrm{~d}$ & $25.83 \mathrm{~h}$ & $44.06 \mathrm{f}$ & $27.03 \mathrm{f}$ & $18.77 \mathrm{e}$ & $25.18 \mathrm{e}$ \\
\hline Hyb.Speedy & $30.06 \mathrm{~d}$ & $38.13 \mathrm{f}$ & $62.89 \mathrm{~d}$ & $27.46 \mathrm{f}$ & $25.86 \mathrm{~d}$ & $49.87 \mathrm{~b}$ \\
\hline Hyb.Super Red & $43.58 \mathrm{c}$ & $35.68 \mathrm{f}$ & $33.79 \mathrm{~h}$ & $38.22 \mathrm{c}$ & $16.56 \mathrm{f}$ & $25.81 \mathrm{e}$ \\
\hline Hyb.SVR 025-7-0830 & $45.9 \mathrm{c}$ & $40.24 \mathrm{f}$ & $73.98 \mathrm{c}$ & $28.9 \mathrm{e}$ & $23.12 \mathrm{~d}$ & $35.37 \mathrm{~d}$ \\
\hline Hyb.SVR025-7-0833 & $47.59 \mathrm{c}$ & $46.86 \mathrm{e}$ & $77.49 \mathrm{~b}$ & $22.86 \mathrm{f}$ & $16.92 \mathrm{f}$ & $44.26 \mathrm{c}$ \\
\hline Hyb.Wadistar & $56.71 \mathrm{~b}$ & $44.57 \mathrm{e}$ & $61.92 \mathrm{c}$ & $34.67 \mathrm{~d}$ & $39.18 \mathrm{~b}$ & $47.04 \mathrm{c}$ \\
\hline Hyb.XTM5230 & $35.43 \mathrm{~d}$ & $21.44 \mathrm{~h}$ & $25.72 \mathrm{i}$ & $22.86 \mathrm{f}$ & $12.78 \mathrm{~g}$ & $13.35 \mathrm{~g}$ \\
\hline Kimia-Falat & $59.59 \mathrm{~b}$ & $39.19 \mathrm{f}$ & $42.6 \mathrm{f}$ & $28.33 \mathrm{e}$ & $19.28 \mathrm{e}$ & $14.04 \mathrm{~g}$ \\
\hline Packmor & $56.56 \mathrm{~b}$ & $28.38 \mathrm{~h}$ & $25.25 \mathrm{i}$ & $24.79 \mathrm{f}$ & $15.92 \mathrm{f}$ & $14.21 \mathrm{~g}$ \\
\hline Rio Grande & $61.54 \mathrm{a}$ & $69.5 \mathrm{~b}$ & $45.16 \mathrm{f}$ & $38.02 \mathrm{c}$ & $37.24 \mathrm{~d}$ & $25.78 \mathrm{e}$ \\
\hline Super 2274 & $59.82 \mathrm{~b}$ & $51.04 \mathrm{~d}$ & $69.54 \mathrm{c}$ & $42.08 \mathrm{~b}$ & $36.18 \mathrm{~b}$ & $44.41 \mathrm{c}$ \\
\hline Viva & $65.24 \mathrm{a}$ & $53.84 \mathrm{~d}$ & $86.88 \mathrm{a}$ & $54.83 \mathrm{a}$ & $45.55 \mathrm{a}$ & $67.02 \mathrm{a}$ \\
\hline $\mathrm{CV}(\%)$ & 9.6 & 8.4 & 8 & 6.2 & 8 & 6.3 \\
\hline
\end{tabular}

${ }^{1 /}$ Means followed by the same letters within the same columns are not significantly different $(\mathrm{P}<0.05)$, Scott-Knott test $)$.

and $86.5 \mathrm{~g}$, respectively, produced the highest tomato yield (Table 1). Yield losses resulting from parasitism reached up to $90.2 \%$ in the susceptible cultivar Hyb. Petopride II, but the infested cultivar Hyb. Eden F1, with 16.4\% reduction compared with its non-infested plant, was the most resistant variety according to this parameter (Table 2). The varieties Caligen 86, Super 2274 and Viva, with 21, 23.5 and $27.3 \%$ reduction, respectively, did not show significant differences compared with the cultivar Hyb. Eden F1 (Table 2).
Significant differences were observed between tomato varieties in the measured parameters for Orobanche $(\mathrm{P}<0.05)$. Different levels of parasitization (number of shoots and dry weight of shoots and tubercles) on tomato varieties were recorded. Emergence date for Orobanche varied over a period of 3 to 30 days in this experiment. The varieties Cal-jN3, Viva, Caligen 86, Packmor, CSX 5013, Hyb. PS 6515 and Hyb. Petopride 5 showed very late infection (data not shown). Delay in Orobanche development or shoot emergence could 
represent a component of resistance. Delaying infection could have a large effect on plant yield. The present results are consistent with the hypothesis of Alders \& Pieterse (1987) that the host may resist parasite development at different development stages including seed germination, shoot emergence and development of flowering shoots.

Orobanche aegyptiaca parasitized the tomato varieties at different intensities according to the produced number of broomrape shoots. The number of emerged spikes per host plant is considered to be an important index (Rubiales et al., 2003; Dor et al., 2010). Results showed that tomato varieties based on the number of Orobanche emerged spikes per host plant can be arranged in 5 groups. The varieties Cal-j N3 and Hyb. Petopride 5 did not have any Orobanche spike; also, the number of Orobanche spikes per plant was significantly lower for the varieties Viva, Packmor, CSX 5013, Hyb.Firenze (PS 8094), Hyb.XTM5230. These varieties were the least

Table 2 - Mean comparison of dry weight of emerged shoots and tubercles (g) and number of emerged broomrape shoots per host plant and \% dry weight reduction of shoot, root and fruit of infested plants compared to non-infested plants(Asin: transformation of arc sine)

\begin{tabular}{|c|c|c|c|c|c|c|c|}
\hline \multirow[b]{2}{*}{ Tomato variety } & \multicolumn{4}{|c|}{ Broomrape } & \multicolumn{3}{|c|}{ Tomato (\% dry weight reduction) } \\
\hline & $\begin{array}{c}\text { Shoot (DW) } \\
\text { (gr) }\end{array}$ & $\begin{array}{c}\text { Tubercles } \\
\text { (DW) } \\
\text { (gr) }\end{array}$ & $\begin{array}{l}\text { Shoot } \\
\text { (No.) }\end{array}$ & $\begin{array}{l}\text { Asin Shoot } \\
\text { (No.) }\end{array}$ & Shoot & Root & Fruit \\
\hline Caligen 86 & $7.2 \mathrm{~d}^{1 / 1}$ & $5.31 \mathrm{e}$ & $5 \mathrm{e}$ & $12.88 \mathrm{c}$ & $92.18 \mathrm{a}$ & $80.54 \mathrm{a}$ & $78.86 \mathrm{a}$ \\
\hline Cal-jN3 & $0 \mathrm{e}$ & $0.03 \mathrm{e}$ & $0 \mathrm{e}$ & $0 \mathrm{e}$ & $51.4 \mathrm{~d}$ & $61.7 \mathrm{c}$ & $40.7 \mathrm{~d}$ \\
\hline chef & $10.98 \mathrm{c}$ & $12.63 \mathrm{~d}$ & $25.67 \mathrm{c}$ & $30.41 \mathrm{~b}$ & $45.8 \mathrm{e}$ & $70.4 \mathrm{~b}$ & $50.5 \mathrm{c}$ \\
\hline CSX 0005 & $9.75 \mathrm{c}$ & $13.8 \mathrm{~d}$ & $23.33 \mathrm{c}$ & $28.89 \mathrm{~b}$ & $83.2 \mathrm{~b}$ & $55.3 \mathrm{c}$ & $57.5 \mathrm{~b}$ \\
\hline CSX 5013 & $5.2 \mathrm{~d}$ & $6.74 \mathrm{e}$ & $2.33 \mathrm{e}$ & $8.75 \mathrm{~d}$ & $73.9 \mathrm{~b}$ & $52.4 \mathrm{~d}$ & $50.2 \mathrm{c}$ \\
\hline CSX 9062 & $6.74 \mathrm{~d}$ & $5.54 \mathrm{e}$ & $23.33 \mathrm{c}$ & $28.85 \mathrm{~b}$ & $40.3 \mathrm{e}$ & $42.3 \mathrm{~d}$ & $26.4 \mathrm{e}$ \\
\hline Early Urbana Y & $12.74 \mathrm{c}$ & $18.62 \mathrm{c}$ & $13.33 \mathrm{~d}$ & $21.41 \mathrm{~b}$ & $82.9 \mathrm{~b}$ & $65.5 \mathrm{~b}$ & $53 \mathrm{c}$ \\
\hline Hyb.Alex 63 F1(XP 02500006) & $6.57 \mathrm{~d}$ & $28.3 \mathrm{~b}$ & $43.67 \mathrm{a}$ & $41.37 \mathrm{a}$ & $94.5 \mathrm{a}$ & $68.6 \mathrm{~b}$ & $51.8 \mathrm{c}$ \\
\hline Hyb.AP865 & $20.37 \mathrm{a}$ & $24.78 \mathrm{~b}$ & $19.67 \mathrm{c}$ & $26.22 \mathrm{~b}$ & $38 \mathrm{f}$ & $35.7 \mathrm{e}$ & $23.6 \mathrm{e}$ \\
\hline Hyb.Berlina(CS 02500008) & $10.64 \mathrm{c}$ & $15.14 \mathrm{~d}$ & $42 \mathrm{a}$ & $40.40 \mathrm{a}$ & $31.9 \mathrm{f}$ & $41.8 \mathrm{~d}$ & $30.9 \mathrm{e}$ \\
\hline Hyb.Eden F1 & $11.26 \mathrm{c}$ & $34.17 \mathrm{a}$ & $29.67 \mathrm{c}$ & $32.53 \mathrm{a}$ & $84.4 \mathrm{~b}$ & $50.9 \mathrm{~d}$ & $83.5 \mathrm{a}$ \\
\hline Hyb.EX 02530416 & $12.37 \mathrm{c}$ & $13.54 \mathrm{~d}$ & $34 \mathrm{~b}$ & $35.68 \mathrm{a}$ & $45 \mathrm{e}$ & $36.5 \mathrm{e}$ & $44.7 \mathrm{~d}$ \\
\hline Hyb.Firenze (PS 8094) & $2.12 \mathrm{e}$ & $4.68 \mathrm{e}$ & $2.67 \mathrm{e}$ & $9.09 \mathrm{~d}$ & $73.6 \mathrm{~b}$ & $57.5 \mathrm{c}$ & $58.5 \mathrm{~b}$ \\
\hline Hyb.FTM 5456 & $13.29 \mathrm{c}$ & $14.89 \mathrm{~d}$ & $29.33 \mathrm{c}$ & $32.5 \mathrm{a}$ & $45.8 \mathrm{e}$ & $34.9 \mathrm{e}$ & $50.9 \mathrm{c}$ \\
\hline Hyb.Petopride 5 & $0 \mathrm{e}$ & $3.46 \mathrm{e}$ & $0 \mathrm{e}$ & $0 \mathrm{e}$ & $63.1 \mathrm{c}$ & $49.1 \mathrm{~d}$ & $23.9 \mathrm{e}$ \\
\hline Hyb.Petopride II & $23.91 \mathrm{a}$ & $16.55 \mathrm{c}$ & $23 \mathrm{c}$ & $28.39 \mathrm{~b}$ & $41.5 \mathrm{e}$ & $28.5 \mathrm{e}$ & $9.8 \mathrm{f}$ \\
\hline Hyb.PS 6515 & $2.59 \mathrm{e}$ & $3.33 \mathrm{e}$ & $8 \mathrm{~d}$ & $16.36 \mathrm{c}$ & $93.2 \mathrm{a}$ & $69 \mathrm{~b}$ & $49.6 \mathrm{c}$ \\
\hline Hyb.PX 02410739 & $7.17 \mathrm{~d}$ & $22.47 \mathrm{c}$ & $16 \mathrm{~d}$ & $23.48 \mathrm{~b}$ & $78.6 \mathrm{~b}$ & $55.9 \mathrm{c}$ & $63.8 \mathrm{~b}$ \\
\hline Hyb.Speedy & $6.07 \mathrm{~d}$ & $7.71 \mathrm{e}$ & $15.33 \mathrm{~d}$ & $22.78 \mathrm{~b}$ & $88.3 \mathrm{a}$ & $67.8 \mathrm{~b}$ & $42.3 \mathrm{~d}$ \\
\hline Hyb.Super Red & $7.56 \mathrm{~d}$ & $9.41 \mathrm{~d}$ & $8.67 \mathrm{~d}$ & $14.09 \mathrm{c}$ & $64.7 \mathrm{c}$ & $46.5 \mathrm{~d}$ & $22.6 \mathrm{e}$ \\
\hline Hyb.SVR 025-7-0830 & $8.44 \mathrm{~d}$ & $9.34 \mathrm{~d}$ & $18.33 \mathrm{c}$ & $25.2 \mathrm{~b}$ & $63 \mathrm{c}$ & $47.2 \mathrm{~d}$ & $38.1 \mathrm{~d}$ \\
\hline Hyb.SVR025-7-0833 & $5.77 \mathrm{~d}$ & $10.87 \mathrm{~d}$ & $23 \mathrm{c}$ & $28.61 \mathrm{~b}$ & $48.0 \mathrm{e}$ & $46.9 \mathrm{~d}$ & $37.0 \mathrm{~d}$ \\
\hline Hyb.Wadistar & $4.07 \mathrm{~d}$ & $7.98 \mathrm{e}$ & $20.67 \mathrm{c}$ & $27.04 \mathrm{~b}$ & $78.8 \mathrm{~b}$ & $71.9 \mathrm{~b}$ & $57.8 \mathrm{~b}$ \\
\hline Hyb.XTM5230 & $0.61 \mathrm{e}$ & $6.63 \mathrm{e}$ & $2.67 \mathrm{e}$ & $9.36 \mathrm{~d}$ & $64.5 \mathrm{c}$ & $59.6 \mathrm{c}$ & $36.6 \mathrm{~d}$ \\
\hline Kimia-Falat & $12.64 \mathrm{c}$ & $17.74 \mathrm{c}$ & $35.67 \mathrm{~b}$ & $36.67 \mathrm{a}$ & $29.6 \mathrm{f}$ & $31.5 \mathrm{e}$ & $25.4 \mathrm{e}$ \\
\hline Packmor & $4.8 \mathrm{~d}$ & $4.24 \mathrm{e}$ & $2 \mathrm{e}$ & $7.95 \mathrm{~d}$ & $61.5 \mathrm{c}$ & $26.7 \mathrm{e}$ & $24.2 \mathrm{e}$ \\
\hline Rio Grande & $16.7 \mathrm{~b}$ & $11.24 \mathrm{~d}$ & $34 \mathrm{~b}$ & $35.62 \mathrm{a}$ & $54.2 \mathrm{~d}$ & $42.4 \mathrm{~d}$ & $44.3 \mathrm{~d}$ \\
\hline Super 2274 & $7.15 \mathrm{~d}$ & $10.5 \mathrm{~d}$ & $22.33 \mathrm{c}$ & $28.19 \mathrm{~b}$ & $85.6 \mathrm{a}$ & $66.4 \mathrm{~b}$ & $76.4 \mathrm{a}$ \\
\hline Viva & $1.34 \mathrm{e}$ & $1.45 \mathrm{e}$ & $2 \mathrm{e}$ & $7.95 \mathrm{~d}$ & $89.3 \mathrm{a}$ & $85.6 \mathrm{a}$ & $72.7 \mathrm{a}$ \\
\hline $\mathrm{CV}(\%)$ & 32.45 & 28.29 & 28.73 & 18.11 & 14.38 & 8.51 & 9.58 \\
\hline
\end{tabular}

${ }^{1 /}$ Means followed by the same letters within the same columns are not significantly different $(\mathrm{P}<0.05)$, Scott-Knott test). 
affected with an average of 0-5 Orobanche shoots per tomato plant. In contrast, the varieties Hyb.Alex 63 F1(XP 02500006) and Hyb. Berlina (CS 02500008) were the most heavily parasitized with a mean number of 43 and 42 Orobanche shoots per tomato plant, respectively. The results of Buschmann et al. (2005) also showed that the broomrape populations in the field, along with tobacco varieties, are different from some varieties: with a mean number of 55 Orobanche shoots per tobacco plant, it was the most heavily parasitized whilst some other varieties were the least susceptible, with an average of 2-10 broomrape shoots per plant (Table 2).

Similarly, significant differences between varieties were successfully recorded when the dry weight of emerged parasites was measured. These differences nearly followed the variety classification previously established when number of spikes was considered. The varieties Cal-jN3 and Hyb. Petopride 5 did not show any shoot of Orobanche. The varieties Hyb.XTM5230, Viva, Hyb. Firenze (PS 8094), and Hyb.PS 6515, whose dry weight of emerged shoots was $65150.61,1.34,2.12$ and $2.59 \mathrm{~g}$, respectively, did not differ from the varieties Cal-jN3 and Hyb.Petopride 5. These varieties were considered to be the most resistant with negligible broomrape shoot dry weight. In contrast, the variety Hyb.Petopride II, with shoot dry weight of $23.9 \mathrm{~g}$, had the greatest shoot dry weight for Orobanche. The variety Hyb.AP865, with shoot dry weight of 20.4 g, did not have a significant difference compared with the cultivar Hyb.Petopride II. These two varieties were considered to be the most susceptible in terms of Orobanche shoot dry weight (Table 2).

Tomato varieties based on the dry weight of Orobanche tubercles per host plant were evaluated in 5 groups. The cultivar Cal-jN3 showed the lowest dry weight of Orobanche tubercles and the varieties Viva, Hyb.PS 6515, Hyb. Petopride 5, Packmor, Hyb. Firenze (PS 8094), Caligen 86, CSX 9062, Hyb.XTM5230, CSX 5013, Hyb.Speedy and Hyb. Wadistar, with DW of 1.4, 3.3, 3.5, 4.2, 4.7, 5.3, 5.5, 6.6, 6.7, 7.7 and $8 \mathrm{~g}$ for Orobanche tubercles did not differ from the cultivar Cal-jN3. The cultivar Hyb.Eden F1 with $34.2 \mathrm{~g}$ had the highest tubercles dry weight for Orobanche. Broomrape is considered to be a strong sink for nutrients and photo assimilates and its strength is a result of the size and number of attachments on the roots (Joel et al., 2007). Our results showed that the total DW of underground attachments before parasite emergence per host plant or total DW of emerged parasites per host plant was correlated with the resistance level of the host plant. Indeed, as a consequence for host resources among attachments, parasite weight depends on both the number of attachments and the host plant (Rubiales et al., 2006).

The present results demonstrated that different tomato varieties showed varying susceptibility to O. aegyptiaca Based on the measured parameters in this study (Tables 1 and 2), the following varieties were consistently ranked among the first seven resistant varieties. These include Viva and Caligen 86, Hyb. PS 6515; 5 parameters for Hyb. Firenze (PS 8094); 4 parameters for Cal-jN3; 3 parameters for Hyb. Petopride 5, Hyb.PS 6515. These varieties were consistently ranked among the first three susceptible varieties in 3 parameters for Kimia-Falat, Hyb. Petopride II, Hyb.AP865.

These findings are consistent with Kasrawi \& Abu-Irmaileh (1989), Qasem \& Kasrawi (1995), El-Halmouch et al. (2006), Dor et al., (2010) and Mariam \& Suwanketnikom (2004), who reported acceptable tomato resistance to Orobanche.

The rapid evolution of Orobanche populations leading to the appearance of new virulent races requires a continuous search for resistance sources, and more research is needed to define the stage at which this putative mechanism of resistance acts. It seems that further research is needed to define the stage at which tomato activates its resistance. It could be a physical barrier to host tissue penetration, or it could involve encapsulation of the penetrated radical, or necrosis (Sillero et al., 2005).

Because Orobanche requires stimulants exuded by the host roots in order to germinate and reach the host root, varieties that exude these stimulants at low levels could be suitable for reducing Orobanche infection. In addition, both the lack of exudation or the exudation of 
inhibitors may prevent host recognition by the parasite and its germination (Whitney \& Carstein, 1981). The use of a resistant crop variety is considered as the most reliable and economically feasible means of Orobanche control. Selection should be performed on varieties which showed promising resistance, such as Viva, Caligen 86, Hyb. PS 6515, Hyb. Firenze (PS 8094) and Cal-jN3. These varieties showed considerable resistance to broomrape under both greenhouse conditions and field conditions.

\section{ACKNOWLEDGMENT}

The authors are grateful to 'Iran Falat Company' for supplying the tomato cultivar seeds.

\section{LITERATURE CITED}

AALDERS, A. J. G.; PIETERS, R. Resistance in Vicia faba to Orobanche crenata: true resistance versus hidden susceptibility. Euphytica, v. 36, n. 1, p. 227-236, 1987.

ABBES, Z. et al. Field evaluation of the resistance of some faba bean (Vicia faba L.) genotypes to the parasitic weed Orobanche foetida Poiret. Crop Protec., v. 26, n. 12, p. 1777-1784, 2007.

BUSCHMANN, H.; GONSIOR, G.; SAUERBORN, J. Pathogenicity of branched broomrape (Orobanche ramosa) populations on tobacco cultivars. Plant Pathol., v. 54, n. 5, p. 650-656, 2005.

DOR, E. et al. Characterization of a novel tomato mutant resistant to the weedy parasites Orobanche and Phelipanche spp. Euphytica, v. 171, n. 3, p. 371-380, 2010.

EIZENBERG, H. et al. Phytotoxic root extract from resistant sunflower (Helianthus annuus L. cv. Ambar) inhibits Orobanche cumana development. In: INTERNATIONAL PARASITIC WEED SYMPOSIUM, 7., 2001, Nantes. Proceedings... Nantes: 2001. p. 190-192.

EIZENBERG, H. et al. Resistance to broomrape (Orobanche spp.) in sunflower (Helianthus annuus L.) is temperature dependent. J. Exper. Bot., v. 54, n. 385, p. 1305-1311, 2003.

EL-HALMOUCH Y.; BENHARRAT, H.; THALOUARN, P. Effect of root exudates from different tomato genotypes on broomrape (O. aegyptiaca) seed germination and tubercle development. Crop Protec., v. 25, n. 5, p. 501-507, 2006.

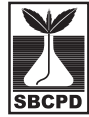

FERNANDEZ-APARICIO, M.; SILLERO, J. C.; RUBIALES, D. Resistance to broomrape species (Orobanche spp.) in common vetch (Vicia sativa L.). Crop Protec., v. 28, n. 1, p. 7-12, 2009.

GOLDWASSER, Y. et al. Biochemical factors involved in vetch resistance to Orobanche aegyptiaca. Plant Pathol., v. 54, n. 1, p. 87-96, 1999.

GOLDWASSER, Y.; KLEIFELD, Y. Tolerance of parsley varieties to Orobanche. Crop Protec., v. 21, n. 10, p. 11011107, 2002.

JOEL, D. M. et al. Biology and management of weedy root parasites. In: JANICK, J. (Ed.). Horticulture reviews. New York: John Wiley \& Sons, 2007. v. 33. p. 267-350.

KASRAWI, M. A.; ABU-IRMAIEH, B. E. Resistance to branched broomrape (Orobanche ramosa L.) in tomato germplasm. Hortic. Sci., v. 24, n. 5, p. 822-824, 1989.

LABROUSSE, P. et al. Several mechanisms are involved in resistance of Helianthus to Orobanche cumana Wallr. An. Bot., v. 88, n. 5, p. 859-868, 2001.

MARIAM, E. G.; SUWANKETNIKOM, R. Screening of tomato (Lycopersicon esculentum Mill.) varieties for resistance to branched broomrape (Orobanche ramosa L.). Kasetsart J. Nat. Sci., v. 38, n. 3, p. 434-439, 2004.

QASEM, J. R.; KASRAWI, M. A. Variation of resistance to broomrape (Orobanche ramosa) in tomatoes. Euphytica, v. 81, n. 1, p. 109-114, 1995.

RUBIALES, D. et al. Characterization of the resistance to Orobanche crenata in chickpea. Weed Sci., v. 51, n. 5, p. 702-707, 2003.

RUBIALES, D. et al. Screening techniques and sources of resistance against parasitic weeds in grain legumes.

Euphytica, v. 147, n. 1/2, p. 187-199, 2006.

SERGHINI, K. et al. Sunflower (Helianthus annuus L.) response to broomrape (Orobanche cernua Loefi.) parasitism: induced synthesis and excretion of 7hydroxylated simple coumarins. J. Exper. Bot., v. 52, n. 364, p. 2227-2234, 2001.

SILLERO, J. C.; MORENO, M. T.; RUBIALES, D. Sources of resistance to crenate broomrape among Species of Vicia. Plant Dis., v. 89, n. 1, p. 22-27, 2005.

SILLERO, J. C.; RUBIALES, D.; CUBERO, J. I. Risks of Orobanche resistance screening based only on number of emerged shoots per plant. In: MORENO, M. T. et al. (Ed.). Advances in parasitic plant research. INTERNATIONAL ON PARASITIC WEEDS SYMPOSIUM, 6., 1996, Cordoba. Proceedings... Cordoba: 1996. p. 651-657.

Planta Daninha, Viçosa-MG, v. 32, n. 1, p. 109-116, 2014 
WHITNEY. P. J.; CARSTEIN, C. Chemotropic response of broomrape radicles to host roots exudates. An. Bot., v. 48, n. 6, p. 919-921, 1981.
ZHOU, W. J. et al. In vitro infection of host roots by differentiated calli of the parasitic plant Orobanche. J. Exper. Bot., v. 55, n. 398, p. 899-907, 2004. 